\title{
Apresentação ao número 34
}

\author{
Mariângela de Araújo \\ Álvaro Faleiros \\ Elena Vássina
}

John Milton

Com grande satisfação finalizamos este ano apresentando aos nossos leitores e colaboradores o $34 .^{\circ}$ número da revista TradTerm. Como é habitual, tivemos um espectro amplo de representação de vários estados brasileiros. Há entre os autores pesquisadores de diferentes cidades do estado de São Paulo, de Minas Gerais e de Pernambuco. Neste número contamos com artigos muito interessantes e gostaríamos de ressaltar que há nele quase que um equilíbrio entre artigos dedicados à Terminologia e à Tradução. Esse fato nos alegra ao demonstrar um incremento no interesse de pesquisadores pela Terminologia e ao dar visibilidade a uma área que tem grande contribuição a oferecer ao desenvolvimento de nosso país, juntamente à Tradução, que impulsiona nossas relações com países e culturas diversos.

Em relação à Tradução, este número da revista contempla, sobretudo, a tradução literária, que demanda do profissional, por um lado, uma veia criativa e, por outro, o respeito às características do texto original, para atender aos anseios de quem lê a obra. Além disso, há um artigo sobre a história da tradução, também literária, no Brasil e outro sobre a formação de tradutores.

TradTerm, São Paulo, v.34, dezembro/2019, p. 1-4 www.revistas. usp.br/tradterm 
Desse modo, encontramos dois artigos relacionados a questões específicas da tradução literária. O primeiro deles, elaborado por Alessandro Palermo Funari e intitulado "Traduzir Anecdote of the Jar, de Wallace Stevens", tem como objetivo analisar o poema Anecdote of the Jar e duas de suas traduções para o português, para verificar as opções e criações realizadas pelos tradutores; em vista dessa análise, o autor do artigo ainda propõe a sua própria tradução do poema. Já, no segundo texto, "As Horas: adaptação de Virginia Woolf para o leitor comum", Ana Carolina de Carvalho Mesquita nos apresenta uma análise sobre um texto adaptado do romance Mrs. Dalloway, de Virginia Woolf. Tratase de um modo mais abrangente de ver a "tradução literária", que demonstra a dificuldade de se verter um texto complexo para um leitor comum, utilizandose da intertextualidade com outros textos da autora.

Ainda em relação aos artigos referentes à Tradução, temos o texto "Três coleções”, em que a autora, Denise Bottmann, nos traz um levantamento histórico de coleções literárias publicadas no Brasil entre 1934 e 1972, com base em obras traduzidas: a Série Negra, a Seleção Labirinto e a Coleção Saraiva. Nesse artigo Denise Bottmann nos demonstra o processo de seleção das obras literárias traduzidas e incorporadas às coleções e as decisões editoriais para a publicação desses textos.

No último artigo referente à Tradução, "Tecnologias da tradução e a pedagogia colaborativa", Marileide Dias Esqueda nos apresenta a tradução como um processo colaborativo, do qual participam vários atores que, de alguma maneira, interferem no resultado final: o texto traduzido. Sendo assim, discute a necessidade de incorporar esse fato, por meio da pedagogia colaborativa, na formação dos tradutores, baseando-se ainda na teoria socioconstrutivista existente nos estudos sobre Educação. Partindo desses pressupostos, a autora demonstra como ferramentas tecnológicas podem contribuir nesse processo colaborativo, utilizando como exemplo o sistema SDL Trados Studio, que fornece uma série de facilidades para grupos atuantes em uma tradução.

TradTerm, São Paulo, v.34, dezembro/2019, p. 1-4 www.revistas. usp.br/tradterm 
No que diz respeito à Terminologia, neste número temos três artigos. Dois deles tratam de áreas de especialidade específicas e o último aborda questões teóricas em Terminologia.

No artigo "Terminologia da Radiação Solar: elaboração de um glossário bilíngue (português-francês)", Renata Tonini Bastianello e Adriana Zavaglia nos apresentam os procedimentos metodológicos e os desafios encontrados na elaboração de um glossário terminológico bilíngue nessa área de especialidade. Destaca-se nesse estudo a aplicação da teoria dos "ganchos terminológicos", proposto por Dubuc (1985), para o estabelecimento de equivalentes quando são usados corpora bilíngues.

Outro artigo relacionado a uma área de especialidade específica é "Análise da variação terminológica denominativa em textos jurídicos: o caso do termo petição inicial". Os autores do artigo, Amanda Henrique Pereira e Odair Luiz Nadin, dedicam-se ao estudo da terminologia do Direito, trazendonos uma análise da variação denominativa no discurso jurídico, baseada na Teoria Comunicativa da Terminologia (Cabré, 1999) e nos estudos de Freixa (2002; 2006 e 2014).

O último artigo que apresentamos é o de Márcia Ivo Braz e Severino Carlos da Silva, intitulado "O conceito de comunidade discursiva e as convergências com a Terminologia". Trata-se de um artigo teórico, que busca aproximar os estudos terminológicos e o conceito de "comunidade discursiva", proposto por Swales (1990). Nesse sentido, os autores, além de discutir o conceito de comunidade discursiva, fazem um levantamento nas bases de dados internacionais WebofScience e Library \& Information Science Abstracts (LISA) e nas bases de dados nacionais BDTD e BRAPCI, a fim de verificar se o conceito tem sido usado em estudos terminológicos. Por meio de seu estudo, ressaltam a necessidade de mais estudos que relacionem as unidades terminológicas aos gêneros textuais e discursivos e evidenciam o fato de que o vocabulário utilizado nas áreas de especialidade constitui-se como uma das características das comunidades discursivas.

TradTerm, São Paulo, v.34, dezembro/2019, p. 1-4 www.revistas.usp.br/tradterm 
Para concluir esta apresentação, agradecemos aos autores, que nos confiaram seus textos tão qualificados, e aos pareceristas deste número, que nos permitiram oferecer a nossos leitores textos tão interessantes. Esperamos poder contar com suas valiosas contribuições em outras oportunidades. Agradecemos ainda a Luiza Lotufo e a Sandra Albuquerque, que muito nos auxiliaram nesta publicação.

Desejamos a todos uma prazerosa e profícua leitura! 